\title{
The neurosteroid progesterone underlies estrogen positive feedback of the LH surge
}

\author{
Paul Micevych ${ }^{1 *}$ and Kevin Sinchak ${ }^{2}$ \\ 1 Laboratory of Neuroendocrinology, Department of Neurobiology, David Geffen School of Medicine, Brain Research Institute, University of California, Los Angeles, \\ CA, USA \\ ${ }^{2}$ Department of Biological Sciences, California State University, Long Beach, CA, USA
}

\section{Edited by:}

Henryk Urbanski, Oregon National

Primate Research Center, USA

\section{Reviewed by:}

A. Kemal Topaloglu, Cukurova

University, Turkey

loannis E. Messinis, University of

Thessalia, Greece

\section{*Correspondence:}

Paul Micevych, Department of Neurobiology, David Geffen School of Medicine, University of California, Los Angeles, CA 90095-1763, USA.

e-mail:pmicevych@mednet.ucla.edu
Our understanding the steroid regulation of neural function has rapidly evolved in the past decades. Not long ago the prevailing thoughts were that peripheral steroid hormones carried information to the brain which passively responded to these steroids. These steroid actions were slow, taking hours to days to be realized because they regulated gene expression. Over the past three decades, discoveries of new steroid receptors, rapid membraneinitiated signaling mechanisms, and de novo neurosteroidogenesis have shed new light on the complexity of steroids actions within the nervous system. Sexual differentiation of the brain during development occurs predominately through timed steroid-mediated expression of proteins and long term epigenetic modifications. In contrast across the estrous cycle, estradiol release from developing ovarian follicles initially increases slowly and then at proestrus increases rapidly. This pattern of estradiol release acts through both classical genomic mechanisms and rapid membrane-initiated signaling in the brain to coordinate reproductive behavior and physiology. This review focuses on recently discovered estrogen receptor- $\alpha$ membrane signaling mechanisms that estradiol utilizes during estrogen positive feedback to stimulate de novo progesterone synthesis within the hypothalamus to trigger the luteinizing hormone (LH) surge important for ovulation and estrous cyclicity. The activation of these signaling pathways appears to be coordinated by the rising and waning of estradiol throughout the estrous cycle and integral to the negative and positive feedback mechanisms of estradiol. This differential responsiveness is part of the timing mechanism triggering the LH surge.

Keywords: estrogen receptor, $\mathrm{ER} \alpha \Delta 4$, membrane estradiol signaling, receptor trafficking

\section{INTRODUCTION}

For decades the prevailing concept was that the brain passively responded to steroids originating from the periphery. These hormones were thought to mediate feedback mechanisms and regulate reproductive circuits. Although the brain does respond directly to ovarian and adrenal steroids, over the years this straight-forward notion has been drastically modified. The nervous system does not just passively respond to peripheral steroids. It actively metabolizes peripheral steroids to biologically active steroids that regulate numerous brain functions. For example, circulating testosterone can be aromatized to estradiol, or reduced to dihydrotestosterone (DHT) and further to $3 \beta$ - or $3 \alpha$-diols that are important in regulating behavior, negative feedback, and sexual differentiation (Lavaque et al., 2006a; Higo et al., 2009). Further, peripheral progesterone can be metabolized to allopregnanolone ( $3 \beta$-hydroxy- $5 \alpha$ pregnan-20-one). Many of these neurally converted metabolites are ligands for nuclear receptors that are transcription factors that modulate gene expression (Roselli et al., 2009). In contrast, other steroid metabolites allosterically bind to and modulate membrane receptor activity. The most notable of this type is allopregnanolone, which activates the $\mathrm{GABA}_{\mathrm{A}}$ receptor (Majewska et al., 1986; Puia et al., 1990; Hosie et al., 2006; Herd et al., 2007; Mitchell et al., 2008).
A surprising discovery was that nervous tissue synthesizes steroids de novo to regulate neural functions and behavior (Baulieu, 1981, 1991, 1998; Mellon, 1994; Schumacher et al., 2003). The steroids synthesized in the nervous system are referred to as neurosteroids (Baulieu, 1981, 1991), and are produced in astrocytes, oligodendrocytes, and neurons. The proteins and enzymes required for de novo steroidogenesis of estradiol from cholesterol are present in the brain. As in the ovary, multiple cell types cooperate in steroidogenesis. The most prevalent neurosteroids are pregnenolone, progesterone, and allopregnanolone (Corpechot et al., 1993), which are synthesized in astrocytes (Zwain and Yen, 1999).

Neurosteroidogenesis studies localized steroidogenic enzymes, enzymatic activity, and transporter proteins in expected and unexpected regions of the nervous system (Follesa et al., 2000; Wehrenberg et al., 2001; Lavaque et al., 2006b). Because of their highly localized synthesis and relatively low levels compared to circulating steroids, measuring, and determining the roles of neurosteroids in physiological, behavioral, and feedback systems has been difficult. In peripheral nerves, neurosteroids are implicated in myelination (Schumacher et al., 2000, 2003, 2004), and have therapeutic actions in the treatment of epilepsy and traumatic brain injury (Dubrovsky, 2005; Morrow, 2007; Reddy and Rogawski, 2009). 
Recently, roles for neurosteroids in reproductive physiology have been defined. Immortalized murine gonadotropin releasing hormone (GnRH) neurons, GT1-1 cells, converted progesterone to allopregnanolone, and stimulated the release of $\mathrm{GnRH}$ by activating the $\mathrm{GABA}_{\mathrm{A}}$ receptor (el-Etr et al., 1995). Another important milestone for understanding the physiology of neurosteroids was demonstrating that the actions of peripheral steroids are integrated with the actions of neurosteroids. This review focuses on this integration controlling ovulation.

\section{ROLE OF NEUROPROGESTERONE AND ITS METABOLITES IN FEMALE REPRODUCTION}

Ovulation, a critical event in mammalian reproduction, is initiated by elevated levels of estradiol released by maturing ovarian follicles which act on the hypothalamus and pituitary. This event, known as estrogen positive feedback, produces a surge of $\mathrm{GnRH}$ from the hypothalamus that stimulates the secretion of luteinizing hormone ( $\mathrm{LH})$ from the pituitary. A puzzling aspect of estrogen positive feedback is that estrogens which are inhibitory to hormone release from the hypothalamus and pituitary gland during most of the cycle (negative feedback) now stimulate these tissues to induce a surge of hormone release, especially the neural network that controls the GnRH neurons (Chazal et al., 1974). Sequential estradiol and progesterone stimulation of the hypothalamus is essential for estrogen positive feedback to culminate in the $\mathrm{LH}$ surge (Chappell and Levine, 2000; Micevych et al., 2003, 2008; Micevych and Sinchak, 2008b). A key step in positive feedback is the estradiol-induced expression of hypothalamic progesterone receptors (PRs; Brom and Schwartz, 1968; Ferin et al., 1969; Labhsetwar, 1970; Rao and Mahesh, 1986; Mahesh and Brann, 1998b). Specifically, transcription and activation of PR-A in the hypothalamus are obligatory events in the induction of the $\mathrm{GnRH}$ and $\mathrm{LH}$ surges in estradiol-primed, ovariectomized (OVX) rats (Chappell and Levine, 2000).

For several years, it was not clear how PR-A was activated. One proposed mechanism was ligand-independent activation of PR that did not require progesterone (Mani et al., 1994, 1996; Mani, 2006). In place of progesterone, dopamine acting through the $\mathrm{DA}_{1}$ receptor would activate $\mathrm{PR}$. Another hypothesized mechanism was that pre-ovulatory progesterone of adrenal origin activated PR. Both the ovary and the adrenal cortex, highly steroidogenic organs, are capable of producing progesterone needed for the LH surge (Mahesh and Brann, 1998a). However, evidence for a peripheral source of progesterone is lacking. A significant rise in progesterone has not been consistently seen in the systemic circulation prior to the LH surge indicating that the progesterone required for the $\mathrm{LH}$ surge may not be synthesized peripherally (Feder et al., 1971; Kalra and Kalra, 1974; Smith et al., 1975). Consistent with this idea is that neither the adrenals nor the ovaries are necessary for an estrogeninduced LH surge (Mann et al., 1976; Sridaran and Blake, 1980). Indeed, OVX and adrenalectomized (ADX) rats primed with only $17 \beta$-estradiol have a robust LH surge (Mann et al., 1976; Micevych et al., 2003). However, inhibiting the enzyme $3 \beta$-hydroxysteroid dehydrogenase ( $3 \beta$-HSD) that converts pregnenolone to progesterone in ADX/OVX rats prevents estradiol induction of the $\mathrm{LH}$ surge, indicating that progesterone is needed for estrogen positive feedback (Micevych et al., 2003).
Since estradiol induces an LH surge in OVX/ADX rats and blocking progesterone signaling inhibits estradiol-induced $\mathrm{LH}$ surges, we hypothesized that the source of this progesterone was the brain. The steroidogenic capacity of the brain has been well-established (Baulieu, 1981, 1991; Corpechot et al., 1981; Le Goascogne et al., 1987; Jung-Testas et al., 1989a,b; Mellon and Deschepper, 1993; Mellon, 1994; Guennoun et al., 1995; Koenig et al., 1995; Sanne and Krueger, 1995). Our investigations demonstrate that the enzymes and carrier proteins are present and that estradiol regulates them in a dose and time dependent manner that is congruent with estradiol levels across the estrous cycle. PCR analysis confirmed that hypothalamic tissue in vivo expresses mRNA for cytochrome P-450 side-chain cleavage (P450scc) and $3 \beta$-HSD, as well as the cholesterol transport protein steroidogenic acute regulatory protein (StAR) - all of the proteins needed to synthesize progesterone from cholesterol (Soma et al., 2005). Like $\mathrm{PR}$, estradiol primes the neurosteroidogenic pathways. Estradiol increased hypothalamic expression $3 \beta$-HSD with a time course that would allow for neuroprogesterone synthesis to occur hours prior to the LH surge and act through estradiol-induced PRs (Soma et al., 2005). The importance of the steroidogenesis in the brain for the LH surge and estrous cycle was demonstrated in gonadally intact cycling rats. On the morning of proestrus, steroidogenesis in the hypothalamus was blocked by infusing aminoglutethimide (AGT), a P-450 side-chain cleavage (P450scc) enzyme inhibitor into the lateral ventricle. Although peripheral levels of estradiol in vehicle and AGT treated rats were similar, the estrous cycle of AGT female was arrested in proestrus and levels of progesterone in the hypothalamus and circulation remained low compared to controls. In AGT treated rats, the uterus was swollen and fluid filled, the ovaries had numerous developing follicles but no forming corpus luteum - all indications that peripheral steroidogenesis was intact. In spite of the typical proestrus rise in circulating estradiol, blocking neurosteroidogenesis prevented the LH surge, ovulation, and luteinization and arrested progression of the estrous cycle (Micevych and Sinchak, 2008a; Figure 1). After several days the effects of AGT wore off and the rats exhibited vaginal cytology of estrus, indicative of the LH surge, and resumed their regular 4-5 day estrous cycles. These data strongly suggest that estradiol stimulates hypothalamic neuroprogesterone synthesis, which is essential in mediating the positive feedback regulation of the LH surge.

It is always interesting to speculate how results in model species, especially rodents, illuminate the mechanism regulating the LH surge and ovulation in women. Typically, circulating levels of progesterone are low to undetectable in most primates and it is only after ovulation and luteinization that circulating levels progesterone rise. In primates, as in rodents, pre-ovulatory progesterone regulates the LH surge. In women, although estradiol alone can induce a LH surge (Leyendecker et al., 1972; Monroe et al., 1972; Yen and Tsai, 1972), treatment with the PR antagonist, RU 486, or inhibitors of progesterone synthesis attenuate the LH surge and prevent ovulation (Collins and Hodgen, 1986; Liu et al., 1987; Shoupe et al., 1987; Batista et al., 1992; Croxatto et al., 1993). These responses in women and non-human primates are consistent with our findings that estrogen positive feedback induces a hypothalamic source of pre-ovulatory progesterone that 


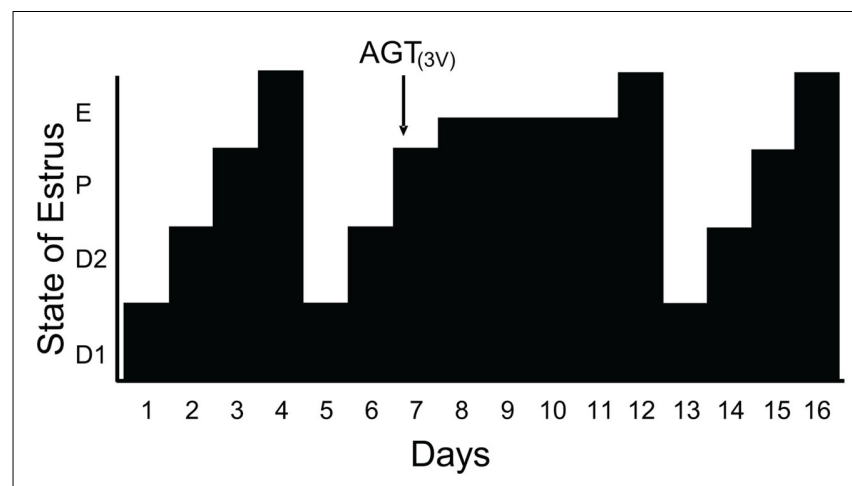

FIGURE 1 | Blocking neuroprogesterone synthesis alters the pattern of estrous cycles in gonadally intact rats. The 4-day rat estrous cycle is diagrammatically presented. Each day of the cycle is indicated on the ordinate: $\mathrm{D} 1$, diestrous day 1 ; $\mathrm{D} 2$, diestrous day 2 ; $\mathrm{P}$, proestrus; and $\mathrm{E}$, estrus. Neuroprogesterone synthesis was blocked by infusion of a P450scc inhibitor, aminoglutethimide (AGT), into the third ventricle (3V) via an implanted cannula. All animals treated with DMSO (5\%, vehicle $n=14$; data not shown) had normal 4 day estrous cycles as determined by vaginal cytology. In contrast, 11/14 AGT treated rats (0800 hours on proestrus, indicated by the arrow) had disrupted estrous cycles with delayed onset of estrous as determined by vaginal cytology (from Micevych and Sinchak, 2008a).

activates neural networks that regulate $\mathrm{GnRH}$ neuronal activity triggering the LH surge. In numerous species progesterone also positively regulates pituitary responsiveness to gonadotropes during estrogen positive feedback (Liu and Yen, 1983; Messinis and Templeton, 1990). In line with this idea, women treated with RU 486 exhibit an attenuated release of $\mathrm{LH}$ in response to exogenous GnRH (Kazem et al., 1996). Together these results indicate that both central and pituitary sites of progesterone action to facilitate estrogen positive feedback. It is likely that the neuroprogesterone synthesized in the hypothalamus could access the pituitary via the hypothalamo-pituitary portal circulation to modulate coordinate pituitary responsiveness with neural portion of the feedback loop.

\section{ESTRADIOL ACTS ON ASTROCYTES}

Astrocytes are responsive to various neuroactive messengers (Hosli and Hosli, 1992; Hirst et al., 1998; Chaban et al., 2004; Oka et al., 2006). Among these modulators of astrocyte function is estradiol which profoundly influences their morphology and function (Mong and Blutstein, 2006), sexual differentiation (McCarthy et al., 2002), and steroidogenesis (Sinchak et al., 2003; Micevych et al., 2007). Astrocytes in turn regulate numerous hypothalamic processes including regulation of releasing factors (Cavarretta et al., 1999; Galbiati et al., 2002; Zwain et al., 2002; Cashion et al., 2003; Mahesh et al., 2006) and synthesis of neurosteroids (Akwa et al., 1993; Jung-Testas et al., 1999; Zwain and Yen, 1999; Zwain et al., 2002). Astrocytes have all the steroidogenic enzymes required to convert cholesterol directly to progesterone (P450scc and $3 \beta$ HSD), and the transport proteins StAR and peripheral benzodiazepine receptor/translocator protein (PBR/TSPO; Schumacher et al., 2004), and are the main source of neuroprogesterone produced within the hypothalamus (Zwain and Yen, 1999; Micevych et al., 2003, 2007, 2008). As with granulosa cells of the ovary, astrocytes express estrogen receptor- $\alpha$ ( (ER $\alpha)$ and $E R \beta$, providing a potential avenue for estradiol regulation of neuroprogesterone steroidogenesis (Azcoitia et al., 1999; Garcia-Segura et al., 1999; Buchanan et al., 2000; Chaban et al., 2004; Pawlak et al., 2005; Quesada et al., 2007).

Both intracellular and membrane-associated ERs have been found in astrocytes. However, the regulation of progesterone synthesis in astrocytes is mediated through estradiol membrane signaling (EMS) that has been described in neurons and peripheral tissues (Szego and Davis, 1967; Kelly et al., 1976; Lagrange et al., 1995; Razandi et al., 1999; Filardo et al., 2000; Ivanova et al., 2001; Wade et al., 2001; Qiu et al., 2003; Chaban et al., 2004; Acconcia et al., 2005; Pawlak et al., 2005; Revankar et al., 2005; Thomas et al., 2005; Mhyre and Dorsa, 2006; Pedram et al., 2006, 2007; Bondar et al., 2009; Hirahara et al., 2009; Kuo et al., 2009). As in neurons, estradiol can influence cell signaling in astrocytes, which express $\mathrm{ER} \alpha$ and $\mathrm{ER} \beta$ both intracellularly and on the plasma membrane (Garcia-Segura et al., 1999; Chaban et al., 2004; Pawlak et al., 2005; Quesada et al., 2007). Activation of the membrane ER (mER) with estradiol or a membrane impermeable construct (estradiolcoupled to bovine serum albumin, E-6-BSA) initiates a rapid intracellular calcium concentration $\left(\left[\mathrm{Ca}^{2+}\right]_{\mathrm{i}}\right)$ increase via activation of the phospholipase C/inositol trisphosphate $\left(\mathrm{PLC} / \mathrm{IP}_{3}\right)$ pathway that releases intracellular stores of calcium from the smooth endoplasmic reticulum in neurons and astrocytes (Beyer and Raab, 1998; Chaban et al., 2004; Micevych et al., 2007). This rise in $\left[\mathrm{Ca}^{2+}\right]_{\mathrm{i}}$ stimulates the de novo synthesis of progesterone in post-pubertal hypothalamic astrocytes within $5 \mathrm{~min}$ (Micevych et al., 2003, 2007; Kuo et al., 2010). The calcium hypothesis was tested by thapsigargin, a potent $\mathrm{Ca}^{2+}$-ATPase inhibitor that rapidly releases $\mathrm{IP}_{3}$-sensitive $\mathrm{Ca}^{2+}$ stores from the smooth endoplasmic reticulum. This thapsigargin-induced massive release of $\mathrm{Ca}^{2+}$ was similar in magnitude to estradiol stimulation and within minutes resulted in progesterone synthesis (Micevych et al., 2007). Likewise, subnanomolar doses of estradiol were sufficient to induce rapid $\left[\mathrm{Ca}^{2+}\right]_{\mathrm{i}}$ release and progesterone synthesis in cultured hypothalamic astrocytes within minutes (Kuo et al., 2009). While the estradiol increase in $\left[\mathrm{Ca}^{2+}\right]_{i}$ was dose-dependent, the synthesis of progesterone displayed a "step function" responding to physiological levels of estradiol that are reached during the proestrus surge (Butcher et al., 1974; Hawkins et al., 1975; Shaikh and Shaikh, 1975). The threshold response to estradiol is consistent with the idea that stimulation of neuroprogesterone synthesis is part of an "off-on-off" mechanism regulating the transition from estrogen negative feedback to estrogen positive feedback, and back again at least in rodents (Kuo et al., 2010). Thus, as estradiol rises with developing ovarian follicles, it gradually increases levels of $\left[\mathrm{Ca}^{2+}\right]_{\mathrm{i}}$ in astrocytes; however, only when estradiol levels peak, consistent with mature follicles, does the $\left[\mathrm{Ca}^{2+}\right]_{\mathrm{i}}$ reach a critical threshold for stimulating progesterone synthesis. This response prevents hypothalamic progesterone levels from rising too early, resulting in a premature LH surge before ovarian follicles are fully mature and ready to ovulate.

\section{MEMBRANE ESTROGEN RECEPTOR SIGNALING}

Understanding the timing and mechanisms involved in estradiol signaling has been made more difficult by discoveries of several 
proteins that act as membrane-associated ERs: ER $\alpha, \mathrm{ER} \beta, \mathrm{ER}-\mathrm{X}$ (Toran-Allerand, 2000; Toran-Allerand et al., 2002), STX-activated protein called mER-Gaq (Qiu et al., 2003, 2006), and GPR30 (Filardo et al., 2000, 2002; Revankar et al., 2005; Thomas et al., 2005). Although neurosteroidogenesis was activated by E-6-BSA, it was blocked by the ER $\alpha$ and $\operatorname{ER} \beta$ antagonist, ICI 182,780, suggesting that this rapid signaling was mediated by these receptors (Chaban et al., 2004; Micevych et al., 2007). In the context of reproductive neuroendocrinology, the evidence is most robust for $\mathrm{ER} \alpha$ as the critical membrane-associated ER. Mouse astrocytes from $\mathrm{ER} \alpha \mathrm{KO}$ mice had a significantly attenuated estradiol-induced $\left[\mathrm{Ca}^{2+}\right]_{\mathrm{i}}$ response (Kuo et al., 2010), which was mirrored in vivo. Priming OVX ER $\alpha$ KO mice with estradiol failed to significantly increase hypothalamic progesterone levels as observed in OVX wild-type mice (Kuo et al., 2010). Most dramatically, ER $\alpha$ was shown to be vital for estrogen positive feedback when mice in which the ER $\alpha$ was deleted from neurons failed to have a LH surge and ovulate (Wintermantel et al., 2006).

Classic nuclear receptors $\mathrm{ER} \alpha$ (and $\mathrm{ER} \beta$ ) have been shown to associate with the plasma membrane through a variety of methods. ER over expression demonstrated that a population of these nuclear proteins are targeted to the plasma membrane (Razandi et al., 1999) where they have been localized with immunohistochemistry, western blotting, and surface biotinylation (Lagrange et al., 1995, 1996; Razandi et al., 1999; Ivanova et al., 2001; Wade et al., 2001; Chaban et al., 2004; Acconcia et al., 2005; Pawlak et al., 2005; Mhyre and Dorsa, 2006; Pedram et al., 2006; Bondar et al., 2009; Dominguez et al., 2009; Hirahara et al., 2009; Kuo et al., 2009; Sakuma et al., 2009; Dominguez and Micevych, 2010).

Membrane ERs were demonstrated in hypothalamic astrocytes and neurons using membrane-impermeable constructs such as E-6-BSA-FITC (1,3,5(10)-estratrien-3,17 $\alpha$-diol-6-onebovine serum albumin-fluorescein isothiocyanate) and E-6-biotin (1,3,5(10)-estratrien-3,17 $\alpha$-diol-6-one-6-carboxymethloxime- $\mathrm{NH}$ propyl-biotin; Dominguez et al., 2009; Micevych and Dominguez, 2009; Micevych et al., 2010). EMS activates G protein-dependent cell signaling cascades (Hammes and Levin, 2007), including activation of the mitogen-activated protein kinase (MAPK) pathway, activation of protein kinase $\mathrm{C}(\mathrm{PKC})$, increasing $\left[\mathrm{Ca}^{2+}\right]_{i}$, and phosphorylation of cAMP-responsive element binding protein (CREB; Dewing et al., 2007, 2008; reviewed by Kelly and Ronnekleiv, 2008). An issue with $\mathrm{ER} \alpha$ mediating EMS is that $\mathrm{ER} \alpha$ is a transcription factor and does not have the canonical structure of a $G$ protein-coupled receptor. An elegant solution was the proposed mechanism in which ligand-activated $\operatorname{mER} \alpha$ or $\operatorname{mER} \beta$ transactivated metabotropic glutamate receptors (mGluRs) to stimulate $\mathrm{PLC} / \mathrm{IP}_{3}$ - MAPK pathways leading to the activation of CREB (Boulware et al., 2005; Dewing et al., 2007). These signaling cascades have been implicated in the estradiol activation of lordosis behavior through neuropeptide expression and receptor activation (Watters and Dorsa, 1998). In astrocytes the interaction of $\operatorname{mER} \alpha$ and mGluRla was necessary to mediate estradiol signaling at the membrane. The increase in $\left[\mathrm{Ca}^{2+}\right]_{\mathrm{i}}$ and progesterone synthesis were blocked with the mGluRla antagonist LY 367,385 (Kuo et al., 2009, 2010). This physiologic evidence was reinforced by the observation that $\mathrm{ER} \alpha$ and mGluRla co-immunoprecipitate in hypothalamic astrocytes (Kuo et al., 2009, 2010). Significantly,
ER $\beta$ did not co-immunoprecipitate with mGluR1a, supporting the idea that of ER $\alpha$ is the mER mediating estradiol induction of progesterone synthesis in hypothalamic astrocytes.

In these in vitro experiments, we observed an interesting phenomenon. Although glutamate was not needed for estradiol transactivation of mGluRla, activation of mGluRla augmented the estradiol response (Kuo et al., 2009, 2010). These results demonstrated that estradiol would be maximally effective at stimulating astrocytes (and progesterone synthesis) when extracellular glutamate was elevated implying that estradiol signaling is strengthened in areas undergoing excitatory neural activity involving glutamate. Under such circumstances, astrocytes are a site of neural-hormonal integration. Indeed, middle-aged females exhibit reduced excitation of GnRH neurons and attenuated $\mathrm{LH}$ surges under estrogen positive feedback conditions, in part, due to decreased glutamate neurotransmission in the medial preoptic area, demonstrating the importance of local modulatory effects on estrogen positive feedback, the LH surge, and reproductive function (Neal-Perry et al., 2005, 2009). Further, it appears that menopause may be induced by the loss of estradiol-induced neuroprogesterone synthesis. As rats enter menopause, estradiol levels increase to intermediate level, though not reaching the estrogen positive feedback levels. However, the elevated estradiol levels are maintained for an extended period of time. The rat is in an extended proestrus state, similar to that induced by AGT infused into the lateral ventricle. Treating the menopausal rats with progesterone induces the LH surge, indicating that the brain is not synthesizing progesterone in response to elevated estradiol but remains responsive to progesterone ( $\mathrm{Lu}$ et al., 1994; Mills et al., 2002). Interestingly, these females are in constant behavioral estrus and the LH surge can be induced by copulating with a male. Thus, female rats appear to become reflex ovulators as they reach their final stages of reproduction. Then after several months of acyclicity, exogenous progesterone can no longer induce the LH surge because estradiol is incapable of inducing PR expression as well as neuroprogesterone synthesis (Mills et al., 2002).

If $\mathrm{ER} \alpha$ is also responsible for EMS, does it have the characteristics of other membrane receptors: present on the surface, trafficked to the membrane, and internalized after stimulation with its ligand? Surface biotinylation studies with hypothalamic astrocytes demonstrated that ER $\alpha$ is located on the cell surface, trafficked to the membrane, and internalized by estradiol treatment. Moreover, the trafficking and internalization are is dependent upon mGluR1a, and blocked by mGluR1a antagonism with LY 367,385 (Bondar et al., 2009). Similarly in hypothalamic neurons, estradiol treatment significantly increased the internalization of mGluRla in parallel with $\mathrm{ER} \alpha$, and that the trafficking is dependent on caveolin (Boulware et al., 2007; Dominguez and Micevych, 2010) further supporting the idea of an ER $\alpha$-mGluR1a signaling unit for EMS (Dominguez and Micevych, 2010).

These experiments revealed that estradiol regulates its own membrane-initiated signaling. Such autoregulation of signaling, for example helps to explain observations in vivo of the transient effect of EMS that affect sexual receptivity and progesterone synthesis (Sinchak and Micevych, 2001, 2003; Micevych et al., 2003; Dewing et al., 2007; Kuo et al., 2009, 2010). Estradiol rapidly, within $5 \mathrm{~min}$, induces $\mathrm{mER} \alpha$ trafficking to the plasma membrane 
(Bondar et al., 2009). Peak mER $\alpha$ levels were achieved by $30 \mathrm{~min}$. Once on the membrane, estradiol activates $\mathrm{ER} \alpha$ and induces internalization. $m E R \alpha$ trafficking and internalization is blocked by either the ER antagonist ICI 182,780, or the mGluR1a antagonist LY 367,385, verifying ER $\alpha$-mGluR1a signaling (Bondar et al., 2009). As expected, trafficking to the membrane and internalization occurred in parallel, with the peak of internalization also at $30 \mathrm{~min}$. A possible mechanism for insertion is the fusion of $\mathrm{mER} \alpha-$ mGluRla containing vesicles with the cell membrane. This idea is supported by the presence of ER $\alpha$ immunoreactive vesicles in the hippocampus and pituitary (Gonzalez et al., 2008). Internalization, like that of other membrane receptors is probably mediated by clathrin-coated endocytic vesicles, which retrieve ligand-bound receptors (Micevych and Dominguez, 2009). Once receptors are internalized, the vesicles fuse with early endosomes and release their ligand. At this juncture, the receptors can either be recycled to the cell surface or degraded (Sinchak and Micevych, 2003; Micevych and Dewing, 2011). Degradation wins out over recycling after a continuous $1-2 \mathrm{~h}$ exposure to estradiol, which leads to a reduction of both surface $m E R \alpha$ and internalized $m E R \alpha$. The loss of $\operatorname{mER} \alpha$ (i.e., down regulation) is a mechanism by which estradiol can temporally limit EMS (Bondar et al., 2009; Dominguez and Micevych, 2010).

\section{ANOTHER $m E R \alpha$ ?}

An unexpected finding of the biotinylation studies was the presence of a 52- to 55-kDa ER $\alpha$ immunoreactive membrane protein. This protein was also found in hypothalamic neuronal membranes and is the product of an alternatively spliced ER $\alpha$ mRNA in which exon 4 is deleted ( $\mathrm{ER} \alpha \Delta 4$; Dominguez et al., submitted). Initially, Crews and colleagues reported such an ER $\alpha$ mRNA (Skipper et al., 1993). They reported that $\mathrm{ER} \alpha \Delta 4$ was very abundant in the brain. Since then, ER $\alpha \Delta 4$ mRNA has been reported in the brain, pituitary, and breast (Fuqua et al., 1992; Bollig and Miksicek, 2000; Deecher et al., 2003; Perlman et al., 2005). We confirmed the presence of the ER $\alpha \Delta 4 \mathrm{mRNA}$. The resulting protein is missing the nuclear localization signal helping to explain the large quantity seen in the membrane (Pasqualini et al., 2001; Bondar et al., 2009; Dominguez and Micevych, 2010; Roepke et al., 2010). The function of the ER $\alpha \Delta 4$ is unclear since the deletion of exon 4 affects the ligand binding domain, calling into question its estradiol dependence for signaling. Further, only the full-length $66 \mathrm{kDa}$ $\mathrm{ER} \alpha \mathrm{co}$-immunoprecipitated with mGluRla, which in astrocytes is needed for the estradiol-induced $\left[\mathrm{Ca}^{2+}\right]_{\mathrm{i}}$ release and progesterone synthesis (Kuo et al., 2009, 2010).

\section{OTHER ERS}

In addition to $m E R \alpha$, several other candidate mERs have been proposed (Filardo et al., 2000; Toran-Allerand, 2000; Qiu et al., 2003). GPR30 is a $\mathrm{G}$ protein-coupled receptor that activates adenylyl cyclase in breast cancer cells lacking $\mathrm{ER} \alpha$ and $\mathrm{ER} \beta$ (Filardo et al., 2000, 2002; Revankar et al., 2005; Thomas et al., 2005). FLAG- and hemagglutinin-tagged GPR30 have been reported at the plasma membrane (Funakoshi et al., 2006; Filardo et al., 2007), but GPR30 could not be identified at the plasma membrane or labeled with surface biotinylation in native astrocytes or neurons (Gorosito et al., 2008; Bondar et al., 2009; Kuo et al., 2010). The GPR30 agonist G-1, a substituted dihydroquinoline (Bologa et al., 2006), stimulated $\left[\mathrm{Ca}^{2+}\right]_{\mathrm{i}}$ release and progesterone synthesis (Kuo et al., 2010); however, G-1 had a dose response curve that was different from estradiol or PPT, the selective ER $\alpha$ agonist. Further, since G-1 ability to stimulate $\left[\mathrm{Ca}^{2+}\right]_{\mathrm{i}}$ release was not blocked by antagonizing mGluR1a (Kuo et al., 2010). This also indicates that GPR30 uses a different signaling mechanism compared to estradiol. The lack of interaction between GPR30 and mGluR1a was confirmed by the absence of co-immunoprecipitation between these proteins (Kuo et al.,2010). While it is difficult to understand the discrepancy with GPR30 localization on the plasma membrane, our results can be interpreted to support the observation of estradiol activation of intracellular GPR30 on the endoplasmic reticulum (Revankar et al., 2005). Activation of GPR30 may directly induce the release of intracellular stores of $\mathrm{Ca}^{2+}$, which in turn stimulates progesterone synthesis.

Another candidate receptor is a membrane-associated binding protein that is $\mathrm{G} \alpha_{\mathrm{q}}$-coupled and activated by estradiol as well as STX, a diphenylacrylamide selective estrogen receptor modulator (SERM; Qiu et al., 2003). STX activity is retained in double $\mathrm{ER} \alpha / \mathrm{ER} \beta$ knock-out mice, but blocked with ICI 182,780 (Qiu et al., 2006). STX does not activate $\operatorname{ER} \alpha$ or $\operatorname{ER} \beta$ and has a six order of magnitude lower binding affinity compared with estradiol for these receptors (Qiu et al., 2003). Unfortunately, this mER$\mathrm{G \alpha}_{\mathrm{q}}$ has much lower affinity for estradiol ( 20-fold) compared with STX (Qiu et al., 2006). However, this STX-activated protein also activates PLC (Qiu et al., 2003), a signaling pathway similar to that activated by ER $\alpha$-mGluR1a. In hypothalamic astrocytes, STX increased $\left[\mathrm{Ca}^{2+}\right]_{i}$ and progesterone synthesis through transactivation of mGluR1a (Kuo et al., 2010). It has been suggested that STX signals through GPR30, such that small interfering RNA directed against GPR30 abolished the STX-induced transcription (Lin et al., 2009). However, estradiol has been reported to activate the $\mathrm{mER}-\mathrm{G} \alpha_{\mathrm{q}}$ signaling pathway in GPR30 knock-out mice (Qiu et al., 2008). In our hands, STX and G-1 produced distinctly different responses in hypothalamic astrocytes (Kuo et al., 2010). Although estradiol and STX responses are blocked by mGluR1a antagonism and activate the same PLC pathway, these actions are mediated through different receptors since STX stimulation of $\mathrm{Ca}^{2+}$ release remains in astrocytes from $\mathrm{ER} \alpha \mathrm{KO}$ mice, where estradiol was ineffective (Kuo et al., 2010). Since ER $\alpha$ KO mice do not demonstrate estrogen positive feedback and lack sexual receptivity due to the lack of estradiol signaling, the STX response in ER $\alpha \mathrm{KO}$ mice is not consistent with a STX-related signaling mechanism for induction of the LH surge or receptivity in female reproduction (Rissman et al., 1997; Ogawa et al., 1998; Wintermantel et al., 2006; Kuo et al., 2010). Therefore, the physiological relevance of STX in reproduction remains to be elucidated, but STX may have a future as a therapeutic agent since it does not have uterotropic actions (Roepke et al., 2010).

Lastly, ER-X has been proposed as an ER during development and following injury, especially in the cortex (Toran-Allerand, 2000; Toran-Allerand et al., 2002). This ER is not inhibited by ICI 182,780 , but is activated by $17 \alpha$-estradiol. ER-X is unique in that it is neither blocked by ICI 182,780 nor is it stereospecific. In fact, it is preferentially activated by $17 \alpha$-estradiol (Toran-Allerand et al., 2002). However, in astrocytes the estradiol action on $\left[\mathrm{Ca}^{2+}\right]_{\mathrm{i}}$ is 
stereospecific (Chaban et al., 2004), and the $17 \beta$-estradiol-induced $\left[\mathrm{Ca}^{2+}\right]_{\mathrm{i}}$ release and progesterone synthesis are inhibited by ICI 182,780 , which is not consistent with an ER-X mediated action (Micevych et al., 2007; Kuo et al., 2009).

In summary, several putative mERs are involved in regulation of $\left[\mathrm{Ca}^{2+}\right]_{\mathrm{i}}$ and progesterone synthesis in hypothalamic astrocytes (Kuo et al., 2010). ER $\alpha$ and the STX-activated G $\alpha q$-mER had a similar pharmacology including their dependence on of mGluR1a to initiate cell signaling. From a reproductive vantage point as well as evidence from wild-type and ERKO hypothalamic astrocytes, $\mathrm{ER} \alpha$ appears to be the primary mER responsible for the rapid cell signaling that leads to an increase in hypothalamic neuroprogesterone (Micevych et al., 2007; Bondar et al., 2009; Kuo et al., 2009, 2010).

\section{IS THE LH SURGE STIMULATED BY PROGESTERONE OR A METABOLITE?}

Overall, there is firm evidence that estradiol stimulates the synthesis of progesterone in the hypothalamus. Progesterone in the brain can be rapidly converted to dihydroprogesterone by neuronal and glial $5 \alpha$-reductases and further to allopregnenolone by astrocytic $3 \alpha$-hydroxysteroid oxide reductase (Corpechot et al., 1993; Mensah-Nyagan et al., 1999). As mentioned earlier, allopregnenolone primarily interacts with the $\mathrm{GABA}_{\mathrm{A}}$ receptor. Classically, the GABA receptors are inhibitory. One hypothesis suggests that GnRH neurons have greater intracellular vs. extracellular chloride concentration, which results in an efflux of chloride rather than an influx - depolarizing the neurons and stimulating GnRH release (DeFazio and Moenter, 2002; Sullivan and Moenter, 2003). Indifferent strains of GT1 neurons, allopregnenolone in one case stimulated the release of GnRH (el Etr et al., 1995) and in another did not affect GnRH release (Sleiter et al., 2009). Interestingly, in the latter study progesterone did inhibit GnRH release through an action on membrane PRs: $\mathrm{mPR} \alpha$ and $\mathrm{mPR} \beta$. The in vivo data are equally inconsistent. In vivo, allopregnenolone inhibited $\mathrm{LH}$ release in OVX, estradiol + progesterone primed rats, an effect that was reversed in the presence of bicuculline (Laconi and Cabrera, 2002). However, bicuculline facilitated GnRH release from acute hypothalamic slices (Giuliani et al., 2001). Further confusing the situation is the observation that progesterone can enhance $\mathrm{LH}$ secretion independently of $\mathrm{GABA}_{\mathrm{A}}$ receptor involvement (Brann et al., 1990). Thus, the role of progesterone in mediating estrogen positive feedback is well-established (Kim and Ramirez, 1982; Drouva et al., 1985; Ke and Ramirez, 1987), but evidence for a role of allopregnenolone is not as robust.

\section{CONCLUSION}

The quest to understand the CNS control of the LH surge and the mechanism of estrogen positive feedback has yielded novel insights about the role of astrocytes, progesterone, and EMS. Specifically, estradiol acting through EMS in astrocytes to induce progesterone synthesis must now be considered when describing the mechanism for estrogen positive feedback in reproductive physiology (Figure 2). Preliminary studies suggest that estradiol produced in the ovary also induces the synthesis of PR-A in kisspeptin (KISS) neurons of the GnRH-control network. KISS neurons, of the anteroventral periventricular nucleus (AVPV) and rostral extent of

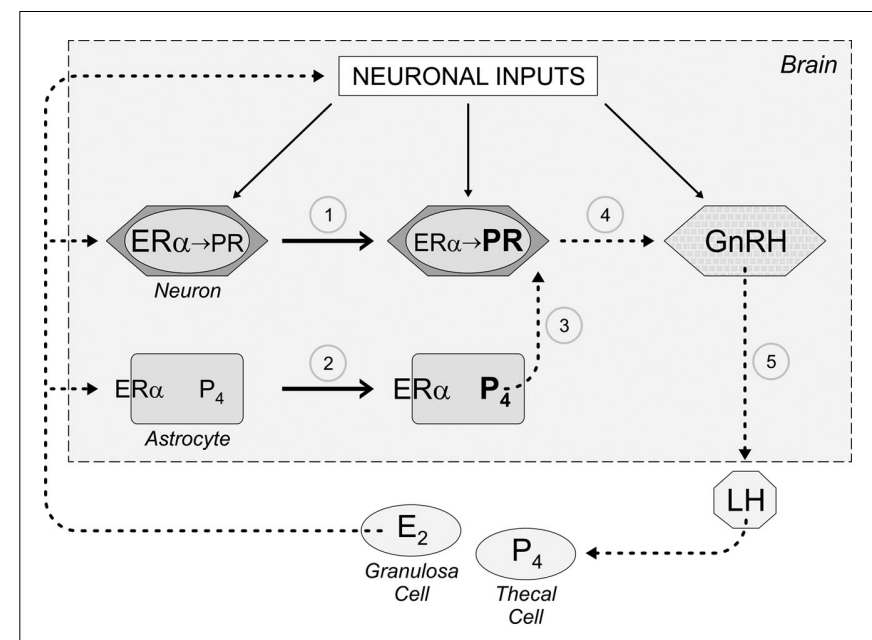

FIGURE 2 | Schematic diagram describing the role of astrocytes, which we propose mediate estrogen positive feedback of the LH surge. As follicles develop in the ovary, granulosa cells under the influence of follicle stimulating hormone (FSH) begin producing estradiol $\left(\mathrm{E}_{2}\right)$. While this level of $E_{2}$ is inhibitory to the neural network regulating the release of $\mathrm{GnRH}$ (negative feedback), this $E_{2}$ induces the expression of progesterone receptors in hypothalamic neurons (1) through activation of nuclear estrogen receptor- $\alpha(E R \alpha)$. When circulating levels of $E_{2}$ peak on proestrus (estrogen positive feedback), $E_{2}$ now binds to $E R \alpha$ on the membrane of astrocytes that transactivates metabotropic glutamate receptor 1a (mGluR1a) increasing cytoplasmic calcium by releasing intracellular calcium stores (positive feedback), which stimulate the synthesis of progesterone $\left(\mathrm{P}_{4} ; 2\right)$. This de novo synthesized $\mathrm{P}_{4}$ diffuses from the astrocyte to bind $E_{2}$-induced $P R$ in nearby neurons (3). We suspect that these neurons use kisspeptin as a transmitter and activate $\mathrm{GnRH}$ neurons (4) causing the surge release of $\mathrm{GnRH}(5)$ that stimulates $\mathrm{LH}$ release form pituitary gonadotropes. The $\mathrm{LH}$ then induces ovulation and luteinization of the follicle in which theca lutein cells synthesize $\mathrm{P}_{4}$

the periventricular nucleus along the III ventricle, project directly to GnRH neurons (Clarkson and Herbison, 2006; Herbison, 2007). KISS is a potent stimulator of GnRH neurons (Messager et al., 2005; d'Anglemont de Tassigny et al., 2008; Herbison, 2008; Liu et al., 2008; Clarkson et al., 2010). Local astrocytes, stimulated by peaking estradiol concentrations, increase progesterone synthesis that activates the PR in KISS neurons to stimulate GnRH release (Figure 2). While a role for membrane PRs has not been elucidated in positive feedback, evidence from GT1 cells suggests that neuroprogesterone from astrocytes can also stimulate membrane PRs, perhaps on native GnRH neurons.

These studies bring into sharp focus that understanding brain function should also involve transmitters regulated at the point of their synthesis. These include the known endocannabinoids, prostaglandins, nitric oxide, and the neurosteroids. In terms estrogen positive feedback regulation of the LH surge and ovulation, neuroprogesterone rather than the metabolite, allopregnenolone that binds to the $\mathrm{GABA}_{\mathrm{A}}$ receptor, appears to be key.

Finally, astrocytes are another point of convergence and integration of hormonal and transmitter signaling (Figure 2). Estradiol, from the periphery binds to $\mathrm{mER}$, which transactivates a mGluR1a receptor to initiate cell signaling that results in a release of intracellular stores $\mathrm{Ca}^{2+}$ and a stimulation of progesterone 
synthesis. Glutamate is not needed for the estradiol-induced $\left[\mathrm{Ca}^{2+}\right]_{\mathrm{i}}$ increase, but in the presence of glutamate, the efficacy of estradiol is increased. Interestingly, in spite of the necessity of $\mathrm{ER} \alpha$ for reproduction, including estrogen positive feedback, STX appears to activate a novel protein that mobilizes $\mathrm{Ca}^{2+}$, stimulates progesterone synthesis but whose actions are blocked by antagonism of the mGluR1a. This suggests a model for EMS in which

\section{REFERENCES}

Acconcia, F., Ascenzi, P., Bocedi, A., Spisni, E., Tomasi, V., Trentalance, A., Visca, P., and Marino, M. (2005). Palmitoylation-dependent estrogen receptor alpha membrane localization: regulation by 17beta-estradiol. Mol. Biol. Cell 16, 231-237.

Akwa, Y., Sananes, N., Gouezou, M., Robel, P., Baulieu, E. E., and Le Goascogne, C. (1993). Astrocytes and neurosteroids: metabolism of pregnenolone and dehydroepiandrosterone. Regulation by cell density. J. Cell Biol. 121, 135-143.

Azcoitia, I., Sierra, A., and GarciaSegura, L. M. (1999). Localization of estrogen receptor betaimmunoreactivity in astrocytes of the adult rat brain. Glia 26, 260-267.

Batista, M. C., Cartledge, T. P., Zellmer, A. W., Nieman, L. K., Merriam, G. R., and Loriaux, D. L. (1992). Evidence for a critical role of progesterone in the regulation of the midcycle gonadotropin surge and ovulation. J. Clin. Endocrinol. Metab. 74, 565-570.

Baulieu, E. E. (1981). "Steroid hormones in the brain: several mechanisms?," in Steroid Hormone Regulation of the Brain, eds K. Fuxe and J. A. Gustafsson (Oxford: Pergamon), 3-14.

Baulieu, E. E. (1991). Neurosteroids: a new function in the brain. Biol. Cell 71, 3-10.

Baulieu, E. E. (1998). Neurosteroids: a novel function of the brain. Psychoneuroendocrinology 23, 963-987.

Beyer, C., and Raab, H. (1998). Nongenomic effects of oestrogen: embryonic mouse midbrain neurones respond with a rapid release of calcium from intracellular stores. Eur. J. Neurosci. 10, 255-262.

Bollig, A., and Miksicek, R. J. (2000). An estrogen receptor-alpha splicing variant mediates both positive and negative effects on gene transcription. Mol. Endocrinol. 14, 634-649.

Bologa, C. G., Revankar, C. M., Young, S. M., Edwards, B. S., Arterburn, J. B., Kiselyov, A. S., Parker, M. A., Tkachenko, S. E., Savchuck, N. P.,
Sklar, L. A., Oprea, T. I., and Prossnitz, E. R. (2006). Virtual and biomolecular screening converge on a selective agonist for GPR30. Nat. Chem. Biol. 2, 207-212.

Bondar, G., Kuo, J., Hamid, N., and Micevych, P. (2009). Estradiolinduced estrogen receptor-alpha trafficking. J. Neurosci. 29, 15323-15330.

Boulware, M. I., Kordasiewicz, H., and Mermelstein, P. G. (2007). Caveolin proteins are essential for distinct effects of membrane estrogen receptors in neurons. J. Neurosci. 27, 9941-9950.

Boulware, M. I., Weick, J. P., Becklund, B. R., Kuo, S. P., Groth, R. D., and Mermelstein, P. G. (2005). Estradiol activates group I and II metabotropic glutamate receptor signaling, leading to opposing influences on cAMP response element-binding protein. J. Neurosci. 25, 5066-5078.

Brann, D. W., Putnam, C. D., and Mahesh, V. B. (1990). Gammaaminobutyric acidA receptors mediate 3 alpha-hydroxy-5 alpha-pregnan-20-one-induced gonadotropin secretion. Endocrinology 126, 1854-1859.

Brom, G. M., and Schwartz, N. B. (1968). Acute changes in the estrous cycle following ovariectomy in the golden hamster. Neuroendocrinology 3, 366-377.

Buchanan, C. D., Mahesh, V. B., and Brann, D. W. (2000). Estrogen-astrocyte-luteinizing hormone-releasing hormone signaling: a role for transforming growth factor-beta(1). Biol. Reprod. 62, 1710-1721.

Butcher, R. L., Collins, W. E., and Fugo, N. W. (1974). Plasma concentration of LH, FSH, prolactin, progesterone and estradiol-17beta throughout the 4-day estrous cycle of the rat. Endocrinology 94, 1704-1708.

Cashion, A. B., Smith, M. J., and Wise, P. M. (2003). The morphometry of astrocytes in the rostral preoptic area exhibits a diurnal rhythm on proestrus: relationship to the luteinizing hormone surge and effects of age. Endocrinology 144, 274-280.

mERs, be they ER $\alpha$, ER $\beta$, or the STX-activated G $\alpha \mathrm{q}$-mER need to transactivate mGluRs. This holds the promise of novel therapeutic approaches for any number of pathologies influenced by estradiol.

\section{ACKNOWLEDGMENTS}

The research from the authors' laboratories was supported by NIH grants: HD04263, DA013185, and HD058638.

Cavarretta, I., Magnaghi, V., Ferraboschi, P., Martini, L., and Melcangi, R. C. (1999). Interactions between type 1 astrocytes and LHRHsecreting neurons (GT1-1 cells): modification of steroid metabolism and possible role of TGFbetal. J. Steroid Biochem. Mol. Biol. 71, 41-47.

Chaban, V. V., Lakhter, A. J., and Micevych, P. (2004). A membrane estrogen receptor mediates intracellular calcium release in astrocytes. Endocrinology 145, 3788-3795.

Chappell, P. E., and Levine, J. E. (2000). Stimulation of gonadotropinreleasing hormone surges by estrogen. I. Role of hypothalamic progesterone receptors. Endocrinology 141, 1477-1485.

Chazal, G., Faudon, M., Gogan, F., and Laplante, E. (1974). Negative and positive effects of oestradiol upon luteinizing hormone secretion in the female rat. J. Endocrinol. 61, 511-512.

Clarkson, J., Han, S. K., Liu, X., Lee, K., and Herbison, A. E. (2010). Neurobiological mechanisms underlying kisspeptin activation of gonadotropin-releasing hormone (GnRH) neurons at puberty. Mol. Cell. Endocrinol. 324, 45-50.

Clarkson, J., and Herbison, A. E. (2006). Postnatal development of kisspeptin neurons in mouse hypothalamus; sexual dimorphism and projections to gonadotropin-releasing hormone neurons. Endocrinology 147, 5817-5825.

Collins, R. L., and Hodgen, G. D. (1986). Blockade of the spontaneous midcycle gonadotropin surge in monkeys by RU 486: a progesterone antagonist or agonist? J. Clin. Endocrinol. Metab. 63, 1270-1276.

Corpechot, C., Robel, P., Axelson, M. Sjovall, J., and Baulieu, E. E. (1981). Characterization and measurement of dehydroepiandrosterone sulfate in rat brain. Proc. Natl. Acad. Sci. U.S.A. 78, 4704-4707.

Corpechot, C., Young, J., Calvel, M., Wehrey, C., Veltz, J. N., Touyer, G., Mouren, M., Prasad, V. V., Banner,
C., and Sjovall, J. (1993). Neurosteroids: 3 alpha-hydroxy-5 alphapregnan-20-one and its precursors in the brain, plasma, and steroidogenic glands of male and female rats. Endocrinology 133, 1003-1009.

Croxatto, H. B., Salvatierra, A. M., Croxatto, H. D., and Fuentealba, B. (1993). Effects of continuous treatment with low dose mifepristone throughout one menstrual cycle. Hum. Reprod. 8, 201-207.

d'Anglemont de Tassigny, X., Fagg, L. A., Carlton, M. B., and Colledge W. H. (2008). Kisspeptin can stimulate gonadotropin-releasing hormone $(\mathrm{GnRH})$ release by a direct action at $\mathrm{GnRH}$ nerve terminals. Endocrinology 149, 3926-3932.

Deecher, D. C., Swiggard, P., Frail, D. E., and O'Connor, L. T. (2003). Characterization of a membrane-associated estrogen receptor in a rat hypothalamic cell line (D12). Endocrine 22, 211-223.

DeFazio, R. A., and Moenter, S. M. (2002). Estradiol feedback alters potassium currents and firing properties of gonadotropin-releasing hormone neurons. Mol. Endocrinol. 16, 2255-2265.

Dewing, P., Boulware, M. I., Sinchak, K., Christensen, A., Mermelstein, P. G., and Micevych, P. (2007). Membrane estrogen receptor-alpha interactions with metabotropic glutamate receptor la modulate female sexual receptivity in rats. J. Neurosci. 27, 9294-9300.

Dewing, P., Christensen, A., Bondar, G., and Micevych, P. (2008). Protein kinase $\mathrm{C}$ signaling in the hypothalamic arcuate nucleus regulates sexual receptivity in female rats. Endocrinology 149, 5934-5942.

Dominguez, R., Hu, E., Zhou, M., and Baudry, M. (2009). 17betaestradiol-mediated neuroprotection and ERK activation require a pertussis toxin-sensitive mechanism involving GRK2 and beta-arrestin-1. J. Neurosci. 29, 4228-4238.

Dominguez, R., and Micevych, P. (2010). Estradiol rapidly regulates membrane estrogen receptor alpha levels in hypothalamic neurons. J. Neurosci. 30, 12589-12596. 
Drouva, S. V., Laplante, E., and Kordon, C. (1985). Progesteroneinduced LHRH release in vitro is an estrogen-as well as $\mathrm{Ca}++-$ and calmodulin-dependent secretory process. Neuroendocrinology 40 , 325-331.

Dubrovsky, B. O. (2005). Steroids, neuroactive steroids and neurosteroids in psychopathology. Prog. Neuropsychopharmacol. Biol. Psychiatry 29, 169-192.

el Etr, M., Akwa, Y., Fiddes, R. J., Robel, P., and Baulieu, E. E. (1995). A progesterone metabolite stimulates the release of gonadotropin-releasing hormone from GT1-1 hypothalamic neurons via the gammaaminobutyric acid type A receptor. Proc. Natl. Acad. Sci. U.S.A. 92, 3769-3773.

el-Etr, M., Akwa, Y., Fiddes, R. J., Robel, P., and Baulieu, E. E. (1995). A progesterone metabolite stimulates the release of gonadotropin-releasing hormone from GT1-1 hypothalamic neurons via the gammaaminobutyric acid type A receptor. Proc. Natl. Acad. Sci. U.S.A. 92, 3769-3773.

Feder, H. H., Brown-Grant, K., and Corker, C. S. (1971). Pre-ovulatory progesterone, the adrenal cortex and the "critical period" for luteinizing hormone release in rats. $J$. Endocrinol. 50, 29-39.

Ferin, M., Tempone, A., Zimmering, P. E., and Van De Wiele, R. L. (1969). Effect of antibodies to 17betaestradiol and progesterone on the estrous cycle of the rat. Endocrinology 85, 1070-1078.

Filardo, E., Quinn, J., Pang, Y., Graeber, C., Shaw, S., Dong, J., and Thomas, P. (2007). Activation of the novel estrogen receptor $G$ proteincoupled receptor 30 (GPR30) at the plasma membrane. Endocrinology 148, 3236-3245.

Filardo, E. J., Quinn, J. A., Bland, K. I., and Frackelton, A. R. Jr. (2000). Estrogen-induced activation of Erk-1 and Erk-2 requires the G protein-coupled receptor homolog, GPR30, and occurs via transactivation of the epidermal growth factor receptor through release of HB-EGF. Mol. Endocrinol. 14, 1649-1660.

Filardo, E. J., Quinn, J. A., Frackelton, A. R. Jr., and Bland, K. I. (2002). Estrogen action via the $G$ protein-coupled receptor, GPR30: stimulation of adenylyl cyclase and cAMP-mediated attenuation of the epidermal growth factor receptor-to-MAPK signaling axis. Mol. Endocrinol. 16, 70-84.
Follesa, P., Serra, M., Cagetti, E., Pisu, M. G., Porta, S., Floris, S., Massa, F., Sanna, E., and Biggio, G. (2000). Allopregnanolone synthesis in cerebellar granule cells: roles in regulation of $\mathrm{GABA}(\mathrm{A})$ receptor expression and function during progesterone treatment and withdrawal. Mol. Pharmacol. 57, 1262-1270.

Funakoshi, T., Yanai, A., Shinoda, K., Kawano, M. M., and Mizukami, Y. (2006). G protein-coupled receptor 30 is an estrogen receptor in the plasma membrane. Biochem. Biophys. Res. Commun. 346, 904-910.

Fuqua, S. A., Fitzgerald, S. D., Allred, D. C., Elledge, R. M., Nawaz,Z., Mcdonnell, D. P., O'Malley, B. W., Greene, G. L., and Mcguire, W. L. (1992). Inhibition of estrogen receptor action by a naturally occurring variant in human breast tumors. Cancer Res. 52, 483-486.

Galbiati, M., Martini, L., and Melcangi, R. C. (2002). Oestrogens, via transforming growth factor alpha, modulate basic fibroblast growth factor synthesis in hypothalamic astrocytes: in vitro observations. $\mathrm{J}$. $\mathrm{Neu}$ roendocrinol. 14, 829-835.

Garcia-Segura, L. M., Naftolin, F., Hutchison, J. B., Azcoitia, I. and Chowen, J. A. (1999). Role of astroglia in estrogen regulation of synaptic plasticity and brain repair. J. Neurobiol. 40, 574-584.

Giuliani, F. A., Yunes, R., Mohn, C. E., Laconi, M., Rettori, V., and Cabrera, R. (2001). Allopregnanolone induces LHRH and glutamate release through NMDA receptor modulation. Endocrine 40, 21-26.

Gonzalez, M., Reyes, R., Damas, C., Alonso, R., and Bello, A. R. (2008). Oestrogen receptor alpha and beta in female rat pituitary cells: an immunochemical study. Gen. Comp. Endocrinol. 155, 857-868.

Gorosito, S. V., Lorenzo, A. G., and Cambiasso, M. J. (2008). Estrogen receptor alpha is expressed on the cell-surface of embryonic hypothalamic neurons. Neuroscience 154, 1173-1177.

Guennoun, R., Fiddes, R. J., Gouezou, M., Lombes, M., and Baulieu, E. E. (1995). A key enzyme in the biosynthesis of neurosteroids, 3 betahydroxysteroid dehydrogenase/delta 5-delta 4 -isomerase ( 3 beta-HSD), is expressed in rat brain. Brain Res. Mol. Brain Res. 30, 287-300.

Hammes, S. R., and Levin, E. R. (2007). Extranuclear steroid receptors: nature and actions. Endocr. Rev. $28,726-741$.
Hawkins, R. A., Freedman, B., Marshall, A., and Killen, E. (1975). Oestradiol17 beta and prolactin levels in rat peripheral plasma. Br. J. Cancer 32, 179-185.

Herbison, A. E. (2007). Estrogen positive feedback to gonadotropinreleasing hormone $(\mathrm{GnRH})$ neurons in the rodent: the case for the rostral periventricular area of the third ventricle (RP3V). Brain Res. Rev. 57 277-287.

Herbison, A. E. (2008). Estrogen positive feedback to gonadotropinreleasing hormone $(\mathrm{GnRH})$ neurons in the rodent: the case for the rostral periventricular area of the third ventricle (RP3V). Brain Res. Rev. 57, 277-287.

Herd, M. B., Belelli, D., and Lambert, J. J. (2007). Neurosteroid modulation of synaptic and extrasynaptic GABA(A) receptors. Pharmacol. Ther. 116, 20-34.

Higo, S., Hojo, Y., Ishii, H., Kominami, T., Nakajima, K., Poirier, D., Kimoto, T., and Kawato, S. (2009). Comparison of sex-steroid synthesis between neonatal and adult rat hippocampus. Biochem. Biophys. Res. Commun. 385, 62-66.

Hirahara, Y., Matsuda, K., Gao, W., Arvanitis, D. N., Kawata, M., and Boggs, J. M. (2009). The localization and non-genomic function of the membrane-associated estrogen receptor in oligodendrocytes. Glia 57, 153-165.

Hirst, W. D., Price, G. W., Rattray, M., and Wilkin, G. P. (1998). Serotonin transporters in adult rat brain astrocytes revealed by $[3 \mathrm{H}] 5$ HT uptake into glial plasmalemmal vesicles. Neurochem. Int. 33, 11-22.

Hosie, A. M., Wilkins, M. E., Da Silva, H. M., and Smart, T. G. (2006). Endogenous neurosteroids regulate GABAA receptors through two discrete transmembrane sites. Nature 444, 486-489.

Hosli, E., and Hosli, L. (1992). Autoradiographic localization of binding sites for arginine vasopressin and atrial natriuretic peptide on astrocytes and neurons of cultured rat central nervous system. Neuroscience 51, 159-166.

Ivanova, T., Karolczak, M., and Beyer, C. (2001). Estrogen stimulates the mitogen-activated protein kinase pathway in midbrain astroglia. Brain Res. 889, 264-269.

Jung-Testas, I., Alliot, F., Pessac, B., Robel, P., and Baulieu, E. E. (1989a). Immunocytochemical localization of cytochrome P-450scc in cultured rat oligodendrocytes. C. R. Acad. Sci. III 308, 165-170.
Jung-Testas, I., Hu, Z. Y., Baulieu, E. E., and Robel, P. (1989b). Neurosteroids: biosynthesis of pregnenolone and progesterone in primary cultures of rat glial cells. Endocrinology 125, 2083-2091.

Jung-Testas, I., Do, T. A., Koenig, H., Desarnaud, F., Shazand, K., Schumacher, M., and Baulieu, E. E. (1999). Progesterone as a neurosteroid: synthesis and actions in rat glial cells. J. Steroid Biochem. Mol. Biol. 69, 97-107.

Kalra, S. P., and Kalra, P. S. (1974). Temporal interrelationships among circulating levels of estradiol, progesterone and LH during the rat estrous cycle: effects of exogenous progesterone. Endocrinology 95, 1711-1718.

Kazem, R., Messinis, L. E., Fowler, P., Groome, N. P., Knight, P. G., and Templeton, A. A. (1996). Effect of mifepristone (RU486) on the pituitary response to gonadotrophin releasing hormone in women. Hum. Reprod. 11, 2585-2590.

Ke, F. C., and Ramirez, V. D. (1987). Membrane mechanism mediates progesterone stimulatory effect on LHRH release from superfused rat hypothalami in vitro. Neuroendocrinology 45, 514-517.

Kelly, M. J., Moss, R. L., and Dudley, C. A. (1976). Differential sensitivity of preoptic-septal neurons to microelectrophoresed estrogen during the estrous cycle. Brain Res. 114, 152-157.

Kelly, M. J., and Ronnekleiv, O. K. (2008). Membrane-initiated estrogen signaling in hypothalamic neurons. Mol. Cell. Endocrinol. 290, 14-23.

Kim, K., and Ramirez, V. D. (1982). In vitro progesterone stimulates the release of luteinizing hormone-releasing hormone from superfused hypothalamic tissue from ovariectomized estradiol-primed prepuberal rats. Endocrinology 111, 750-757.

Koenig, H. L., Schumacher, M., Ferzaz, B., Thi, A. N., Ressouches, A., Guennoun, R., Jung-Testas, I., Robel, P., Akwa, Y., and Baulieu, E. E. (1995). Progesterone synthesis and myelin formation by Schwann cells. Science 268, 1500-1503.

Kuo, J., Hamid, N., Bondar, G., Prossnitz, E. R., and Micevych, P. (2010). Membrane estrogen receptors stimulate intracellular calcium release and progesterone synthesis in hypothalamic astrocytes. J. Neurosci. 30, 12950-12957. 
Kuo, J., Hariri, O. R., Bondar, G., Ogi, J., and Micevych, P. (2009). Membrane estrogen receptor-alpha interacts with metabotropic glutamate receptor type la to mobilize intracellular calcium in hypothalamic astrocytes. Endocrinology 150, 1369-1376.

Labhsetwar, A. P. (1970). Role of estrogens in ovulation: a study using the estrogen-antagonist, I.C.I. 46,474. Endocrinology 87, 542-551.

Laconi, M. R., and Cabrera, R. J. (2002). Effect of centrally injected allopregnanolone on sexual receptivity, luteinizing hormone release, hypothalamic dopamine turnover, and release in female rats. Endocrine 17, 77-83.

Lagrange, A., Wagner, E., Ronnekleiv, O., and Kelly, M. (1996). Estrogen rapidly attenuates a GABAB response in hypothalamic neurons. Neuroendocrinology 64, 114-123.

Lagrange, A. H., Ronnekleiv, K., and Kelly, M. J. (1995). Estradiol-17 $\beta$ and $\mu$-opioid peptides rapidly hyperpolarize GnRH neurons: a cellular mechanism of negative feedback. Endocrinology 136, 2341-2344.

Lavaque, E., Mayen, A., Azcoitia, I., Tena-Sempere, M., and GarciaSegura, L. M. (2006a). Sex differences, developmental changes, response to injury and cAMP regulation of the mRNA levels of steroidogenic acute regulatory protein, cytochrome p450scc, and aromatase in the olivocerebellar system. J. Neurobiol. 66, 308-318.

Lavaque, E., Sierra, A., Azcoitia, I., and Garcia-Segura, L. M. (2006b). Steroidogenic acute regulatory protein in the brain. Neuroscience 138, 741-747.

Le Goascogne, C., Robel, P., Gouezou, M., Sananes, N., Baulieu, E. E., and Waterman, M. (1987). Neurosteroids: cytochrome P-450scc in rat brain. Science 237, 1212-1215.

Leyendecker, G., Wardlaw, S., and Nocke, W. (1972). Experimental studies on the endocrine regulations during the periovulatory phase of the human menstrual cycle. The effects of exogenous 17 -oestradiol and progesterone on the release of pituitary luteinizing and follicle stimulating hormones. Acta Endocrinol. (Copenh) 71, 160-178.

Lin, B. C., Suzawa, M., Blind, R. D., Tobias, S. C., Bulun, S. E., Scanlan, T. S., and Ingraham, H. A. (2009). Stimulating the GPR30 estrogen receptor with a novel tamoxifen analogue activates SF-1 and promotes endometrial cell proliferation. Cancer Res. 69, 5415-5423.
Liu, J. H., Garzo, G., Morris, S., Stuenkel, C., Ulmann, A., and Yen, S. S. (1987). Disruption of follicular maturation and delay of ovulation after administration of the antiprogesterone RU486. J. Clin. Endocrinol. Metab. 65, 1135-1140.

Liu, J. H., and Yen, S. S. (1983). Induction of midcycle gonadotropin surge by ovarian steroids in women: a critical evaluation. J. Clin. Endocrinol. Metab. 57, 797-802.

Liu, X., Lee, K., and Herbison, A. E. (2008). Kisspeptin excites gonadotropin-releasing hormone neurons through a phospholipase $\mathrm{C} /$ calcium-dependent pathway regulating multiple ion channels. Endocrinology 149, 4605-4614.

Lu, J. K., Anzalone, C. R., and Lapolt, P. S. (1994). Relation of neuroendocrine function to reproductive decline during aging in the female rat. Neurobiol. Aging 15, 541-544.

Mahesh, V. B., and Brann, D. W. (1998a). Neuroendocrine mechanisms underlying the control of gonadotropin secretion by steroids. Steroids 63, 252-256.

Mahesh, V. B., and Brann, D. W. (1998b). Regulation of the preovulatory gonadotropin surge by endogenous steroids. Steroids 63, 616-629.

Mahesh, V. B., Dhandapani, K. M., and Brann, D. W. (2006). Role of astrocytes in reproduction and neuroprotection. Mol. Cell. Endocrinol. 246, 1-9.

Majewska, M. D., Harrison, N. L., Schwartz, R. D., Barker, J. L., and Paul, S. M. (1986). Steroid hormone metabolites are barbituratelike modulators of the GABA receptor. Science 232, 1004-1007.

Mani, S. K. (2006). Signaling mechanisms in progesteroneneurotransmitter interactions. Neuroscience 138, 773-781.

Mani, S. K., Allen, J. M., Clark, J. H., Blaustein, J. D., and O'Malley, B. W. (1994). Convergent pathways for steroid hormone- and neurotransmitter-induced rat sexual behavior. Science 265, 1246-1249.

Mani, S. K., Allen, J. M., Lydon, J. P., Mulac-Jericevic, B., Blaustein, J. D., Demayo, F. J., Conneely, O., and O’Malley, B. W. (1996). Dopamine requires the unoccupied progesterone receptor to induce sexual behavior in mice. Mol. Endocrinol. 10, 1728-1737.

Mann, D. R., Korowitz, C. D., Macfarland, L. A., and Cost, M. G. (1976). Interactions of the lightdark cycle, adrenal glands and time of steroid administration in determining the temporal sequence of $\mathrm{LH}$ and prolactin release in female rats. Endocrinology 99, 1252-1262.

McCarthy, M. M., Amateau, S. K., and Mong, J. A. (2002). Steroid modulation of astrocytes in the neonatal brain: implications for adult reproductive function. Biol. Reprod. 67, 691-698.

Mellon, S. H. (1994). Neurosteroids: biochemistry, modes of action, and clinical relevance. J. Clin. Endocrinol. Metab. 78, 1003-1008.

Mellon, S. H., and Deschepper, C. F. (1993). Neurosteroid biosynthesis: genes for adrenal steroidogenic enzymes are expressed in the brain. Brain Res. 629, 283-292.

Mensah-Nyagan, A. G., Do-Rego, J. L., Beaujean, D., Luu-The, V., Pelletier, G., and Vaudry, H. (1999). Neurosteroids: expression of steroidogenic enzymes and regulation of steroid biosynthesis in the central nervous system. Pharmacol. Rev. 51, 63-81.

Messager, S., Chatzidaki, E. E., Ma, D., Hendrick, A. G., Zahn, D., Dixon, J., Thresher, R. R., Malinge, I., Lomet, D., Carlton, M. B., Colledge, W. H., Caraty, A., and Aparicio, S. A. (2005). Kisspeptin directly stimulates gonadotropinreleasing hormone release via G protein-coupled receptor 54 . Proc. Natl. Acad. Sci. U.S.A. 102, 1761-1766.

Messinis, I. E., and Templeton, A. A. (1990). Effects of supraphysiological concentrations of progesterone on the characteristics of the oestradiol-induced gonadotrophin surge in women. J. Reprod. Fertil. 88, 513-519.

Mhyre, A. J., and Dorsa, D. M. (2006). Estrogen activates rapid signaling in the brain: role of estrogen receptor alpha and estrogen receptor beta in neurons and glia. Neuroscience 138, 851-858.

Micevych, P., Bondar, G., and Kuo, J. (2010). Estrogen actions on neuroendocrine glia. Neuroendocrinology 91, 211-222.

Micevych, P., and Dominguez, R. (2009). Membrane estradiol signaling in the brain. Front. Neuroendocrinol. $\quad 30: 315-327$. doi:10.1016/j.yfrne.2009.04.011

Micevych, P., and Sinchak, K. (2008a). Estradiol regulation of progesterone synthesis in the brain. Mol. Cell. Endocrinol. 290, 44-50.

Micevych, P., and Sinchak, K. (2008b). Synthesis and function of hypothalamic neuroprogesterone in reproduction. Endocrinology 149, 2739-2742.

Micevych, P., Sinchak, K., Mills, R. H., Tao, L., Lapolt, P., and Lu, J. K.
(2003). The luteinizing hormone surge is preceded by an estrogeninduced increase of hypothalamic progesterone in ovariectomized and adrenalectomized rats. Neuroendocrinology 78, 29-35.

Micevych, P., Soma, K. K., and Sinchak, K. (2008). Neuroprogesterone: key to estrogen positive feedback? Brain Res. Rev. 57, 470-480.

Micevych, P. E., Chaban, V., Ogi, J., Lakhter, A., Lu, J. K. H., and Sinchak, K. (2007). Estradiol stimulates progesterone synthesis in hypothalamic astrocyte cultures. Endocrinology 148, 782-789.

Micevych, P. E., and Dewing, P. (2011). Membrane-initiated estradiol signaling regulating sexual receptivity. Front. Endocrinol. 2:26. doi:10.3389/fendo.2011.00026

Mills, R. H., Romeo, H. E., Lu, J. K., and Micevych, P. E. (2002). Sitespecific decrease of progesterone receptor mRNA expression in the hypothalamus of middle-aged persistently estrus rats. Brain Res. 955, 200-206.

Mitchell, E. A., Herd, M. B., Gunn, B. G., Lambert, J. J., and Belelli, D. (2008). Neurosteroid modulation of GABAA receptors: molecular determinants and significance in health and disease. Neurochem. Int. 52, 588-595.

Mong, J. A., and Blutstein, T. (2006). Estradiol modulation of astrocytic form and function: implications for hormonal control of synaptic communication. Neuroscience 138, 967-975.

Monroe, S. E., Jaffe, R. B., and Midgley, A. R. Jr. (1972). Regulation of human gonadotropins. XII. Increase in serum gonadotropins in response to estradiol. J. Clin. Endocrinol. Metab. 34, 342-347.

Morrow, A. L. (2007). Recent developments in the significance and therapeutic relevance of neuroactive steroids - introduction to the special issue. Pharmacol. Ther. 116, 1-6.

Neal-Perry, G., Lebesgue, D., Lederman, M., Shu, J., Zeevalk, G. D., and Etgen, A. M. (2009). The excitatory peptide kisspeptin restores the luteinizing hormone surge and modulates amino acid neurotransmission in the medial preoptic area of middleaged rats. Endocrinology 150, 3699-3708.

Neal-Perry, G. S., Zeevalk, G. D., Santoro, N. F., and Etgen, A. M. (2005). Attenuation of preoptic area glutamate release correlates with reduced luteinizing hormone secretion in middle-aged female rats. Endocrinology 146, 4331-4339. 
Ogawa, S., Eng, V., Taylor, J., Lubahn, D. B., Korach, K. S., and Pfaff, D. W. (1998). Roles of estrogen receptor-alpha gene expression in reproduction-related behaviors in female mice. Endocrinology 139, 5070-5081.

Oka, M., Wada, M., Wu, Q., Yamamoto, A., and Fujita, T. (2006). Functional expression of metabotropic GABAB receptors in primary cultures of astrocytes from rat cerebral cortex. Biochem. Biophys. Res. Commun. 341, 874-881.

Pasqualini, C., Guivarc'h, D., Barnier, J. V., Guibert, B., Vincent, J. D., and Vernier, P. (2001). Differential subcellular distribution and transcriptional activity of sigmaE3, sigmaE4, and sigmaE3-4 isoforms of the rat estrogen receptor-alpha. $\mathrm{Mol}$. Endocrinol. 15, 894-908.

Pawlak, J., Karolczak, M., Krust, A., Chambon, P., and Beyer, C. (2005). Estrogen receptor-alpha is associated with the plasma membrane of astrocytes and coupled to the MAP/Src-kinase pathway. Glia 50, 270-275.

Pedram, A., Razandi, M., and Levin, E. R. (2006). Nature of functional estrogen receptors at the plasma membrane. Mol. Endocrinol. 20, 1996-2009.

Pedram, A., Razandi, M., Sainson, R. C., Kim, J. K., Hughes, C. C., and Levin, E. R. (2007). A conserved mechanism for steroid receptor translocation to the plasma membrane. J. Biol. Chem. 282, 22278-22288.

Perlman, W. R., Matsumoto, M., Beltaifa, S., Hyde, T. M., Saunders, R. C., Webster, M. J., Rubinow, D. R., Kleinman, J. E., and Weickert, C. S. (2005). Expression of estrogen receptor alpha exon-deleted mRNA variants in the human and nonhuman primate frontal cortex. $\mathrm{Neu}$ roscience $134,81-95$.

Puia, G., Santi, M. R., Vicini, S., Pritchett, D. B., Purdy, R. H., Paul, S. M., Seeburg, P. H., and Costa, E. (1990). Neurosteroids act on recombinant human GABAA receptors. Neuron 4, 759-765.

Qiu, J., Bosch, M. A., Tobias, S. C., Grandy, D. K., Scanlan, T. S., Ronnekleiv, O. K., and Kelly, M. J. (2003). Rapid signaling of estrogen in hypothalamic neurons involves a novel G-protein-coupled estrogen receptor that activates protein kinase C. J. Neurosci. 23, 9529-9540.

Qiu, J., Bosch, M. A., Tobias, S. C., Krust, A., Graham, S. M., Murphy, S. J., Korach, K. S., Chambon, P., Scanlan, T. S., Ronnekleiv, O. K., and Kelly, M. J. (2006). A Gprotein-coupled estrogen receptor is involved in hypothalamic control of energy homeostasis. J. Neurosci. 26, 5649-5655.

Qiu, J., Ronnekleiv, O. K., and Kelly, M. J. (2008). Modulation of hypothalamic neuronal activity through a novel G-protein-coupled estrogen membrane receptor. Steroids 73, 985-991.

Quesada, A., Romeo, H. E., and Micevych, P. (2007). Distribution and localization patterns of estrogen receptor-beta and insulin-like growth factor-1 receptors in neurons and glial cells of the female rat substantia nigra: localization of ERbeta and IGF-1R in substantia nigra. $J$. Comp. Neurol. 503, 198-208.

Rao, I. M., and Mahesh, V. B. (1986). Role of progesterone in the modulation of the preovulatory surge of gonadotropins and ovulation in the pregnant mare's serum gonadotropin-primed immature rat and the adult rat. Biol. Reprod. 35, 1154-1161.

Razandi, M., Pedram, A., Greene, G., and Levin, E. (1999). Cell membrane and nuclear estrogen receptors (ERs) originate from a single transcript: studies of ERalpha and ERbeta expressed in Chinese hamster ovary cells. Mol. Endocrinol. 13, 307-319.

Reddy, D. S., and Rogawski, M. A. (2009). Neurosteroid replacement therapy for catamenial epilepsy. Neurotherapeutics 6, 392-401.

Revankar, C. M., Cimino, D. F., Sklar, L. A., Arterburn, J. B., and Prossnitz, E. R. (2005). A transmembrane intracellular estrogen receptor mediates rapid cell signaling. Science 307, 1625-1630.

Rissman, E. F., Early, A. H., Taylor, J. A., Korach, K. S., and Lubahn, D. B. (1997). Estrogen receptors are essential for female sexual receptivity. Endocrinology 138, 507-510.

Roepke, T. A., Bosch, M. A., Rick, E. A., Lee, B., Wagner, E. J., SeidlovaWuttke, D., Wuttke, W., Scanlan, T. S., Ronnekleiv, O. K., and Kelly, M. J. (2010). Contribution of a membrane estrogen receptor to the estrogenic regulation of body temperature and energy homeostasis. Endocrinology 151, 4926-4937.

Roselli, C. E., Liu, M., and Hurn, P. D. (2009). Brain aromatization: classic roles and new perspectives. Semin. Reprod. Med. 27, 207-217.

Sakuma, S., Tokuhara, D., Hattori, H., Matsuoka, O., and Yamano, T. (2009). Expression of estrogen receptor alpha and beta in reactive astrocytes at the male rat hippocampus after status epilepticus. Neuropathology 29, 55-62.

Sanne, J. L., and Krueger, K. E. (1995). Expression of cytochrome $\mathrm{P} 450$ side-chain cleavage enzyme and 3 beta-hydroxysteroid dehydrogenase in the rat central nervous system: a study by polymerase chain reaction and in situ hybridization. $J$. Neurochem. 65, 528-536.

Schumacher, M., Akwa, Y., Guennoun, R., Robert, F., Labombarda, F. Desarnaud, F., Robel, P., De Nicola, A. F., and Baulieu, E. E. (2000). Steroid synthesis and metabolism in the nervous system: trophic and protective effects. J. Neurocytol. 29, 307-326.

Schumacher, M., Guennoun, R., Robert, F., Carelli, C., Gago, N., Ghoumari, A., Gonzalez Deniselle, M. C., Gonzalez, S. L., Ibanez, C., Labombarda, F., Coirini, H., Baulieu, E. E., and De Nicola, A. F. (2004). Local synthesis and dual actions of progesterone in the nervous system: neuroprotection and myelination. Growth Horm. IGF Res. (Suppl. A), S18-S33.

Schumacher, M., Weill-Engerer, S., Liere, P., Robert, F., Franklin, R. J., Garcia-Segura, L. M., Lambert, J. J., Mayo, W., Melcangi, R. C., Parducz, A., Suter, U., Carelli, C., Baulieu, E. E., and Akwa, Y. (2003). Steroid hormones and neurosteroids in normal and pathological aging of the nervous system. Prog. Neurobiol. 71, 3-29.

Shaikh, A. A., and Shaikh, S. A. (1975). Adrenal and ovarian steroid secretion. Endocrinology 96, 37-44.

Shoupe, D., Mishell, D. R. Jr., Page, M. A., Madkour, H., Spitz, I. M., and Lobo, R. A. (1987). Effects of the antiprogesterone RU 486 in normal women. II. Administration in the late follicular phase. Am. J. Obstet. Gynecol. 157, 1421-1426.

Sinchak, K., and Micevych, P. (2003). Visualizing activation of opioid circuits by internalization of $\mathrm{G}$ proteincoupled receptors. Mol. Neurobiol. 27, 197-222.

Sinchak, K., and Micevych, P. E. (2001). Progesterone blockade of estrogen activation of $\mu$-opioid receptors regulates reproductive behavior. $\mathrm{J}$. Neurosci. 21, 5723-5729.

Sinchak, K., Mills, R. H., Tao, L., Lapolt, P., Lu, J. K., and Micevych, P. (2003). Estrogen induces de novo progesterone synthesis in astrocytes. Dev. Neurosci. 25, 343-348.

Skipper, J. K., Young, L. J., Bergeron, J. M., Tetzlaff, M. T., Osborn, C. T., and Crews, D. (1993). Identification of an isoform of the estrogen receptor messenger RNA lacking exon four and present in the brain. Proc. Nat. Acad. Sci. 90, 7172-7175.

Sleiter, N., Pang, Y., Park, C., Horton, T. H., Dong, J., Thomas, P., and Levine, J. E. (2009). Progesterone receptor A (PRA) and
PRB-independent effects of progesterone on gonadotropin-releasing hormone release. Endocrinology 150, 3833-3844.

Smith, M. S., Freeman, M. E., and Neill, J. D. (1975). The control of progesterone secretion during the estrous cycle and early pseudopregnancy in the rat: prolactin, gonadotropin and steroid levels associated with rescue of the corpus luteum of pseudopregnancy. Endocrinology 96, 219-226.

Soma, K. K., Sinchak, K., Lakhter, A., Schlinger, B. A., and Micevych, P. E. (2005). Neurosteroids and female reproduction: estrogen increases 3beta-HSD mRNA and activity in rat hypothalamus. Endocrinology 146, 4386-4390.

Sridaran, R., and Blake, C. A. (1980). Effects of long-term adrenalectomy on periovulatory increases in serum gonadotrophins and ovulation in rats. J. Endocrinol. 84, 75-82.

Sullivan, S. D., and Moenter, S. M. (2003). Neurosteroids alter gammaaminobutyric acid postsynaptic currents in gonadotropin-releasing hormone neurons: a possible mechanism for direct steroidal control. Endocrinology 144, 4366-4375.

Szego, C. M., and Davis, J. S. (1967). Adenosine $3^{\prime}, 5^{\prime}$-monophosphate in rat uterus: acute elevation by estrogen. Proc. Natl. Acad. Sci. U.S.A. 58, 1711-1718.

Thomas, P., Pang, Y., Filardo, E. J., and Dong, J. (2005). Identity of an estrogen membrane receptor coupled to a $G$ protein in human breast cancer cells. Endocrinology 146, 624-632.

Toran-Allerand, C. D. (2000). Novel sites and mechanisms of oestrogen action in the brain. Novartis Found. Symp. 230, 56-69; discussion 69-73.

Toran-Allerand, C. D., Guan, X., Maclusky, N. J., Horvath, T. L., Diano, S., Singh, M., Connolly, E. S. Jr., Nethrapalli, I. S., and Tinnikov, A. A. (2002). ER-X: a novel, plasma membrane-associated, putative estrogen receptor that is regulated during development and after ischemic brain injury. J. Neurosci. 22, 8391-8401.

Wade, C. B., Robinson, S., Shapiro, R. A., and Dorsa, D. M. (2001). Estrogen receptor (ER) alpha and ERbeta exhibit unique pharmacologic properties when coupled to activation of the mitogen-activated protein kinase pathway. Endocrinology 142, 2336-2342.

Watters, J. J., and Dorsa, D. M. (1998). Transcriptional effects of estrogen on neuronal neurotensin gene expression involve cAMP/protein kinase A-dependent signaling mechanisms. J. Neurosci. 18, 6672-6680. 
Wehrenberg, U., Prange-Kiel, J., and Rune, G. M. (2001). Steroidogenic factor-1 expression in marmoset and rat hippocampus: co-localization with StAR and aromatase. J. Neurochem. 76, 1879-1886.

Wintermantel, T. M., Campbell, R. E., Porteous, R., Bock, D., Grone, H. J., Todman, M. G., Korach, K. S., Greiner, E., Perez, C. A., Schutz, G., and Herbison, A. E. (2006). Definition of estrogen receptor pathway critical for estrogen positive feedback to gonadotropin-releasing hormone neurons and fertility. Neuron 52, 271-280.
Yen, S. S., and Tsai, C. C. (1972). Acute gonadotropin release induced by exogenous estradiol during the midfollicular phase of the menstrual cycle. J. Clin. Endocrinol. Metab. 34, 298-305.

Zwain, I. H., Arroyo, A., Amato, P., and Yen, S. S. (2002). A role for hypothalamic astrocytes in dehydroepiandrosterone and estradiol regulation of gonadotropinreleasing hormone $(\mathrm{GnRH})$ release by GnRH neurons. Neuroendocrinology 75, 375-383.

Zwain, I. H., and Yen, S. S. (1999). Neurosteroidogenesis in astrocytes, oligodendrocytes, and neurons of cerebral cortex of rat brain. Endocrinology 140 3843-3852.

Conflict of Interest Statement: The authors declare that the research was conducted in the absence of any commercial or financial relationships that could be construed as a potential conflict of interest.

Received: 27 September 2011; paper pending published: 19 October 2011 accepted: 16 November 2011; published online: 02 December 2011.
Citation: Micevych $P$ and Sinchak $K$ (2011) The neurosteroid progesterone underlies estrogen positive feedback of the LH surge. Front. Endocrin. 2:90. doi: 10.3389/fendo.2011.00090

This article was submitted to Frontiers in Genomic Endocrinology, a specialty of Frontiers in Endocrinology. Copyright () 2011 Micevych and Sinchak. This is an open-access article distributed under the terms of the Creative Commons Attribution Non Commercial License, which permits non-commercial use, distribution, and reproduction in other forums, provided the original authors and source are credited. 